\title{
Magnetically Recoverable and Reusable Titanium Dioxide Nanocomposite for Water Disinfection
}

\author{
Monica Keeley ${ }^{1}$, Kim Kisslinger ${ }^{2}$, Carman Adamson ${ }^{1}$ and Ping Y. Furlan ${ }^{1, *(D)}$ \\ 1 Math \& Science Department, United States Merchant Marine Academy, 300 Steamboat Road, Kings Point, \\ NY 11024, USA; mmkeeley2@gmail.com (M.K.); Carmen.Adamson.2022@midshipman.usmma.edu (C.A.) \\ 2 Central for Functional Materials, Brookhaven National Laboratory, 735 Brookhaven Avenue, Upton, \\ NY 11973, USA; kisslinger@bnl.gov \\ * Correspondence: furlanp@usmma.edu
}

Citation: Keeley, M.; Kisslinger, K.; Adamson, C.; Furlan, P.Y.

Magnetically Recoverable and

Reusable Titanium Dioxide

Nanocomposite for Water

Disinfection. J. Mar. Sci. Eng. 2021, 9, 943. https://doi.org/10.3390/jmse 9090943

Academic Editor: Dong-Sheng Jeng

Received: 22 July 2021

Accepted: 27 August 2021

Published: 30 August 2021

Publisher's Note: MDPI stays neutral with regard to jurisdictional claims in published maps and institutional affiliations.

Copyright: (C) 2021 by the authors. Licensee MDPI, Basel, Switzerland. This article is an open access article distributed under the terms and conditions of the Creative Commons Attribution (CC BY) license (https:/ / creativecommons.org/licenses/by/ $4.0 /)$.

\begin{abstract}
A bifunctional magnetic $\mathrm{Fe}_{3} \mathrm{O}_{4} @ \mathrm{SiO}_{2} @ \mathrm{TiO}_{2}$ or $\mathrm{MS}-\mathrm{TiO}_{2}$ antimicrobial nanocomposite was prepared based on simple sol-gel methods with common equipment and chemicals. Reaction $\mathrm{pH}$ was found to influence the $\mathrm{TiO}_{2}$ upload in the nanocomposite. The alkaline condition produced the greatest $\mathrm{TiO}_{2}$ upload, while the acidic condition the least. Annealing at $300{ }^{\circ} \mathrm{C}$ turned the assynthesized amorphous $\mathrm{TiO}_{2}$ into one with high content of anatase, the most photoactive form of $\mathrm{TiO}_{2}$. Irradiated by $365 \mathrm{~nm}$ UV light, a sample of $30 \mathrm{mg} / \mathrm{mL}$ of annealed nanocomposite containing $12.6 \mathrm{wt}$ \% Ti was shown to be able to completely eradicate $10^{4} \mathrm{CFU} / \mathrm{mL}$ of the laboratory-grown E. coli within $25 \mathrm{~min}, 25 \mathrm{~min}$ faster than the control when the $365 \mathrm{~nm}$ UV light was employed alone. The nanocomposite demonstrated consistent antimicrobial performance over repeated uses and was easily recoverable magnetically due to its high magnetization value ( $33 \mathrm{emu} / \mathrm{g}$ ). Additionally, it was shown to reduce the bacterial count in a real surface water sample containing $500-5000 \mathrm{CFU} / \mathrm{mL}$ of different microbes by $62 \pm 3 \%$ within $30 \mathrm{~min}$. The irradiating $365 \mathrm{~nm}$ UV light alone was found to have generated little biocidal effect on this surface water sample. The nanocomposite is promising to serve as an effective, safe, and eco-friendly antimicrobial agent, especially for surface water disinfection.
\end{abstract}

Keywords: anatase; photocatalytic inactivation; nanocomposite; magnetic; water disinfection; surface water; photocatalyst; pH effect; sol-gel

\section{Introduction}

Water from natural sources often contains bacteria, viruses, and fungi that can render this water unable to meet standards for consumption or use. The maritime industry has a demand for disinfected water to meet both ballast, potable, and drinking water regulations. For safe and efficient modern shipping operations, ballast water is essential, which is the seawater carried in ship tanks to improve stability and balance. It is taken in at one location when cargo is unloaded and discharged at another when cargo is loaded. This is one of the major ways that invasive microorganisms can be transported into new marine environments, posing serious ecological, economic, and health issues [1-3]. The ballast water regulation set by the International Maritime Organization (IMO) to prevent the spread of disease and invasive species is outlined in Annex D, which states a limit of Escherichia coli (E. coli) less than 250 CFU per $100 \mathrm{~mL}$ (CFU = colony forming units). The ballast water standard from the United States Coast Guard in 33 CFR 151.1510 requires that ballast water discharged must be treated beforehand unless the ship is at least 200 nautical miles from shore. Additionally, the United States Coast Guard Code of Federal Regulations (CFRs) has a purity standard of at least 99.9 percent (3-log) inactivation of Giardia lamblia cysts and 99.99 percent (4-log) inactivation of viruses for drinking water. Current water disinfection methods include chlorination, filtration, and ultraviolet (UV) radiation [4-7]. However, chlorination has been shown to produce carcinogenic disinfection byproducts 
(DBPs) [8,9], and filtration and UV radiation is costly and can be quite time-consuming [10]. Recently, advances in nanomaterials have triggered large interest in specifically designed components and structures for water treatment with high efficiency and low cost, especially aiming at their applications in marine environments [11-21].

Photocatalytic inactivation is considered a promising alternative for the removal of pathogens from water, as it can be potentially used without generating harmful byproducts under solar irradiation and ambient conditions. Titanium dioxide $\left(\mathrm{TiO}_{2}\right)$ nanoparticles are regarded as one of the most suitable materials because of their high catalytic activity, excellent chemical and thermal stability, and low toxicity and cost $[22,23]$. The semiconductor of $\mathrm{TiO}_{2}$ is found in three crystalline forms, namely, anatase, rutile, and brookite, with band gap values of $3.20 \mathrm{eV}(387 \mathrm{~nm}), 3.02 \mathrm{eV}(411 \mathrm{~nm})$, and $2.96 \mathrm{eV}(419 \mathrm{~nm})$, respectively. Thus, the light of wavelength less than $387 \mathrm{~nm}$ will have energy larger than $3.20 \mathrm{eV}$ to overcome these band gaps, especially that of anatase, to excite $\mathrm{e}^{-}$from the valence band to the conduction band, producing an electron-hole $\left(\mathrm{e}^{-}-\mathrm{h}^{+}\right)$pair on the $\mathrm{TiO}_{2}$ surface [24]. If the semiconductor is suspended in water, redox reactions can take place. The electrons and holes will react with the dissolved oxygen and water molecules nearby to form ROS (reactive oxygen species), including hydroxyl radicals $(\bullet \mathrm{OH})$ and superoxide anion radicals $\left(\mathrm{O}_{2}{ }^{-}\right)$, which are strong oxidants for the disinfection of bacteria [25]. Of all three forms, anatase is found to be the most photoactive and presents the highest antimicrobial effect of $\mathrm{TiO}_{2}$ [26].

Although $\mathrm{TiO}_{2}$ is regenerative and theoretically reusable since it accepts or loses electrons from or to the species in its aqueous environments, its large-scale application as an effective photocatalyst is hindered due to the difficulty of recycling the $\mathrm{TiO}_{2}$ powders in an aqueous treatment. The nanoparticles may be difficult to recover and are readily lost during the dispersion and recovery cycles. To enhance separation and recovery, an attractive strategy is to impart the magnetic properties to the photocatalytic system by coating $\mathrm{TiO}_{2}$ onto magnetic nanoparticles, such as magnetite $\left(\mathrm{Fe}_{3} \mathrm{O}_{4}\right)$ nanoparticles. Magnetite nanoparticles are often chosen for their unique magnetic properties (supermagnetic with high saturation magnetization value) and easy preparation [27]. Akvarez et al. prepared $\mathrm{Fe}_{3} \mathrm{O}_{4} / \mathrm{TiO}_{2}$ and $\mathrm{Fe}_{3} \mathrm{O}_{4} / \mathrm{SiO}_{2} / \mathrm{TiO}_{2}$ (referred to as $\mathrm{MS}-\mathrm{TiO}_{2}$ ) nanoparticles and reported that incorporating a silica layer between the $\mathrm{Fe}_{3} \mathrm{O}_{4}$ core and photocatalyst shell not only reduced the negative effect of magnetite on the photocatalysis process of $\mathrm{TiO}_{2}$ but also protected the magnetic core against oxidation, retaining magnetic properties of the nanocomposite and enriching its removal efficiency [28]. Recently, a few publications described the construction of recyclable photocatalytic nanocomposites of $\mathrm{Fe}_{3} \mathrm{O}_{4} / \mathrm{SiO}_{2} / \mathrm{TiO}_{2}$ with core-shell structure using sol-gel methods [29-34]. These studies focused on the nanocomposite's ability to photodegrade various organic pollutants. Surprisingly, little data were made available addressing the antimicrobial properties of $\mathrm{Fe}_{3} \mathrm{O}_{4} / \mathrm{SiO}_{2} / \mathrm{TiO}_{2}$ due to its $\mathrm{TiO}_{2}$ photocatalytic component in either laboratory-controlled conditions or real-world environments such as surface waters [35]. Additionally, none of the reports investigated the possible effect of $\mathrm{pH}$ on the upload of $\mathrm{TiO}_{2}$ onto the nanocomposite. Sol-gel methods are preferred for synthesizing magnetized $\mathrm{TiO}_{2}$ due to their simplicity in terms of equipment and slow reaction processes, which lead to excellent homogeneity of products and low temperature used, which is cost-effective [34]. The chemistry of the sol-gel process is mainly based on hydrolysis (Equation (1)) and polycondensation (Equations (2) and (3)) of titanium alkoxides, leading to the formation of the extended $\mathrm{TiO}_{2}$ network:

$$
\begin{gathered}
\mathrm{Ti}-\mathrm{OR}+\mathrm{H}_{2} \mathrm{O} \rightarrow \mathrm{Ti}-\mathrm{OH}+\mathrm{ROH} \\
\mathrm{Ti}-\mathrm{OH}+\mathrm{RO}-\mathrm{Ti} \rightarrow \mathrm{Ti}-\mathrm{O}-\mathrm{Ti}+\mathrm{ROH} \\
\mathrm{Ti}-\mathrm{OH}+\mathrm{HO}-\mathrm{Ti} \rightarrow \mathrm{Ti} \rightarrow \mathrm{Ti}-\mathrm{O}-\mathrm{Ti}+\mathrm{H}_{2} \mathrm{O}
\end{gathered}
$$

The $\mathrm{pH}$ values may profoundly affect not only the relative rates of hydrolysis and polycondensation but also the interaction between the silica shell and the titanium clus- 
ters [36], and thus the upload of $\mathrm{TiO}_{2}$ in the final products that directly impacts the products' antimicrobial efficacy.

In the present study, we utilized our recently reported eco-friendly procedure [27] and coated the chemically prepared magnetite nanoparticles with an ultrathin silica layer (referred to as $\mathrm{Fe}_{3} \mathrm{O}_{4} @ \mathrm{SiO}_{2}$ or MS). We then prepared $\mathrm{Fe}_{3} \mathrm{O}_{4} @ \mathrm{SiO}_{2} @ \mathrm{TiO}_{2}$ or $\mathrm{MS}-\mathrm{TiO}_{2}$ nanocomposites via a sol-gel method using titanium tetraisopropoxide (TTIP) precursor as the titanium source under acidic, neutral, and alkaline conditions. To our knowledge, we were the first to show how $\mathrm{pH}$ may affect the amount of $\mathrm{TiO}_{2}$ incorporated into the final product, which would directly impact the product's antimicrobial performance. The synthesized core-multishell nanocomposite was evaluated for its antimicrobial capabilities against an indicator organism, Escherichia coli (E. coli), in water based on the photo-activities of the $\mathrm{TiO}_{2}$ component under $365 \mathrm{~nm} \mathrm{UV}$ radiation. Its reusability and easy post-operational recovery by applying an external magnetic field were also demonstrated. Since ballast water is typically a surface level water, this study, in particular, exemplified the feasibility and applicability of the magnetic nanocomposite for disinfecting a Long Island Sound (LIS) surface water sample, collected at noon on a clear August day and containing a wide range of bacteria, by reducing the bacterial counts of the treated water. These surface water bacteria, unlike the laboratory-grown E. coli, demonstrated little susceptibility to $365 \mathrm{~nm}$ UV radiation. Using superparamagnetic magnetite nanoparticles (MNPs) in combination with the photocatalyst $\mathrm{TiO}_{2}$, the water disinfection methods currently employed in the maritime industry may be greatly improved to save time, money, resources, and energy.

\section{Materials and Methods}

\subsection{Chemicals}

Concentrated hydrochloric acid $(\mathrm{HCl}, 36.5-38.0 \%)$, iron(II) chloride tetrahydrate $\left(\mathrm{FeCl}_{2} \cdot 4 \mathrm{H}_{2} \mathrm{O}\right)$, iron(III) chloride hexahydrate $\left(\mathrm{FeCl}_{3} \cdot 6 \mathrm{H}_{2} \mathrm{O}\right)$, concentrated ammonia $\left(\mathrm{NH}_{3}\right.$, 26-30\%), ethanol (90-95\% ethanol, denatured), and isopropyl alcohol were purchased from VWR International (Radnor, PA, USA). Tetraethyl orthosilicate (TEOS), titanium isopropoxide (TIPP), and neodymium magnets from Applied Magnets (Plano, TX, USA). Escherichia coli (E. coli) K-12 strain, Lysogeny Broth (LB), and LB nutrient agar were obtained from a Microbes and Health Kit purchased from Bio-Rad (Hercules, CA, USA). All chemicals were used as received without any further purification, and all syntheses were carried out under ambient conditions.

\subsection{Synthesis of $\mathrm{Fe}_{3} \mathrm{O}_{4} @ \mathrm{SiO}_{2}(\mathrm{MS})$}

The synthesis of MS core-shell structure was described previously [27]. Briefly, $40 \mathrm{~mL}$ of $1.0 \mathrm{M} \mathrm{FeCl}_{3}$ was mixed with $10 \mathrm{~mL}$ of $2.0 \mathrm{M} \mathrm{FeCl}_{2}$. Under shaking, $\mathrm{Fe}_{3} \mathrm{O}_{4}$ nanoparticles formed immediately as $350 \mathrm{~mL}$ of $1.4 \mathrm{M} \mathrm{NH}_{3}$ was added dropwise to the mixture. After washing with deionized water and drying, $0.10 \mathrm{~g}$ of $\mathrm{Fe}_{3} \mathrm{O}_{4}$ nanoparticles was added to $100 \mathrm{~mL}$ of deionized water, followed by the addition of $5 \mathrm{~mL}$ of concentrated $\mathrm{NH}_{3}$. A total of $2 \mathrm{~mL}$ of TEOS were then added to the mixture. The reaction was allowed to continue for $24 \mathrm{~h}$ in a shaker shaking at $250 \mathrm{rpm}$ at room temperature, producing a less than $5 \mathrm{~nm}$ thin silica coating on $\mathrm{Fe}_{3} \mathrm{O}_{4}$ nanoparticles, which were washed with deionized water, collected using a magnet, and dried at $60^{\circ} \mathrm{C}$.

\subsection{Synthesis of $\mathrm{Fe}_{3} \mathrm{O}_{4} @ \mathrm{SiO}_{2} @ \mathrm{TiO}_{2}$}

$\mathrm{TiO}_{2}$ nanoparticles were incorporated into MS nanocomposite via a sol-gel reaction of TIPP and water. First, Solution A was prepared by dissolving $1.05 \mathrm{~mL}$ of TIPP in $10.6 \mathrm{~mL}$ of isopropyl alcohol, and Solution $\mathrm{B}$ by dissolving $0.17 \mathrm{~mL}$ of $\mathrm{H}_{2} \mathrm{O}$ in $11.5 \mathrm{~mL}$ of isopropyl alcohol. The effect of $\mathrm{pH}$ on the amount of $\mathrm{TiO}_{2}$ attached to $\mathrm{MS}$ was investigated by adjusting the $\mathrm{pH}$ of Solution $\mathrm{B}$ to 3,7 , and 10 by adding $\mathrm{HNO}_{3}$ or $\mathrm{NH}_{3}$ dropwise. Solutions $\mathrm{A}$ and $\mathrm{B}$ were then combined in the presence of varying amounts of MS nanocomposite ranging from 12.5 to $70 \mathrm{mg}$, and the mixture was stirred at room temperature in a shaker

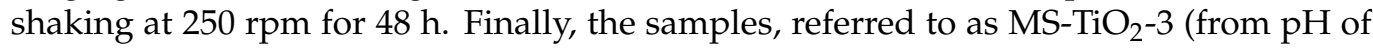




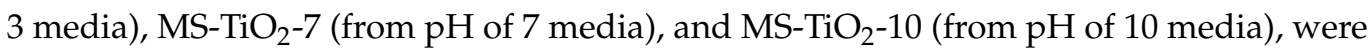
rinsed with water, collected magnetically, and dried at $60{ }^{\circ} \mathrm{C}$. The corresponding $\mathrm{TiO}_{2}$ component control samples were separately prepared by varying the $\mathrm{pH}$ and repeating the procedures without the presence of MS nanocomposite. The samples were annealed at $300{ }^{\circ} \mathrm{C}$ for $5-7$ days to encourage a high degree of transformation of $\mathrm{TiO}_{2}$ from the assynthesized mostly amorphous phase to anatase while avoiding a potential phase transition of magnetite to hematite at elevated temperatures above $400{ }^{\circ} \mathrm{C}[31,37,38]$.

\subsection{Material Characterization}

The as-prepared samples were investigated via Fourier transform infrared spectroscopy (FTIR; Bruker Alpha II Platinum spectrometer, Harvard, MA, USA) using the attenuated total reflection (ATR) accessory equipped with a single reflection diamond crystal. Spectra were collected at a resolution of $4 \mathrm{~cm}^{-1}$ with 24 scans from 400 to $4000 \mathrm{~cm}^{-1}$. $\mathrm{X}$-ray diffraction $(\mathrm{XRD})$ patterns were recorded with a Rigaku MiniFlex, using $\mathrm{Cu} \mathrm{K}$ alpha radiation (wavelength $1.5406 \AA$ ) at $40 \mathrm{kV}, 15 \mathrm{~mA}$, and in the 2-theta range of 10-90 For the annealed $\mathrm{MS}_{-} \mathrm{TiO}_{2}$ sample, the XRD measurement was completed on Rigaku SmartLab universal diffractometer using copper X-ray tube (MSE Supplies LLC, Tucson, AZ, USA). The data were collected using 1D mode detection mode with XRF reduction to decrease fluorescence signal from iron (BNL, Upton, NY, USA). Particle sizes and morphology were characterized by high-resolution transmission electron microscopy (HRTEM), with the images obtained through a JEOL 2100F TEM at $200 \mathrm{kV}$, after adding 1-2 drops of diluted dispersions of the particles onto 200 mesh carbon-coated copper grids (BNL, Upton, NY, USA). The chemical compositions of the samples were analyzed by energy-dispersive $X$-ray spectroscopy (EDS, $20 \mathrm{keV}$ ) which was coupled with the TEM (BNL, Upton, NY, USA). The elemental maps of the samples were also obtained by scanning electron microscopy (SEM; Coxem CX-Plus 200, Yuseong-gu, Daejeon, Korea)-EDS using the Aztec Live model by Oxford (Concord, MA, USA). The samples for SEM were prepared by adding 1-2 drops of dilute dispersions of the particles on pieces of carbon tape attached to aluminum stabs and allowing the particles to dry. The images taken for EDS were at a $15 \mathrm{~cm}$ working distance using $15 \mathrm{keV}$. A vibrating sample magnetometer (VSM; GE \& R, San Diego, CA, USA) was used with an applied field between -10 and $+10 \mathrm{MG}$ at room temperature to study the magnetic properties of the nanocomposites.

\subsection{Antimicrobial Experiments}

The antimicrobial properties of magnetic $\mathrm{MS}-\mathrm{TiO}_{2}$ nanocomposites were investigated against a model microorganism, E. coli bacteria, and the microbes in a sample of Long Island Sound (LIS) surface water. Cells of an E. coli K-12 strain were inoculated into liquid culture of LB broth and incubated at $37^{\circ} \mathrm{C}$ for $24 \mathrm{~h}$. The resulting cell suspension served as the E. coli stock, and was further diluted to give concentrations of $10^{4} \mathrm{CFU} / \mathrm{mL}$. The antimicrobial activity was evaluated based on viable microbial colonies on nutrient agar plates. The microbes were allowed to grow in an incubator at $37^{\circ} \mathrm{C}$ for $24 \mathrm{~h}$.

\subsubsection{Shaking Tests}

The magnetic nanocomposite, with an amount ranging from $1 \mathrm{mg}$ to $30 \mathrm{mg}$, was added to $1.0 \mathrm{~mL}$ of $E$. coli suspensions having concentrations of $10^{4} \mathrm{CFU} / \mathrm{mL}$. Under exposure to $365 \mathrm{~nm}$ wavelength UV light (realUV ${ }^{\mathrm{TM}}$ LED Flood Light, Vancouver, WA, USA), the suspension was continuously agitated at room temperature for a selected length of time. The supernatant was sampled at chosen time intervals after magnetic separation, and $6 \mu \mathrm{L}$ of it was inoculated onto a nutrient agar plate to check microbial reduction over time. A control sample containing E. coli suspension was treated with solely UV light for comparison purposes. 


\subsubsection{Reusability Tests}

A quantity of $5 \mathrm{mg}$ of $\mathrm{MS}-\mathrm{TiO}_{2}-10$ was used to treat $1 \mathrm{~mL}$ of $E$. coli suspension having a concentration of $10^{4} \mathrm{CFU} / \mathrm{mL}$. Under the exposure of $365 \mathrm{~nm}$ wavelength $\mathrm{UV}$ light, the reusability was tested by repeating a 21 min shaking test at room temperature three times. Sampling was performed at 3 min interval after magnetic separation, and $6 \mu \mathrm{L}$ of supernatant was taken and placed on a nutrient agar plate.

\subsubsection{Disinfection of Long Island Sound (LIS) Surface Water}

The feasibility of employing the $\mathrm{MS}^{-\mathrm{TiO}_{2}}$ nanocomposites for disinfecting Long Island Sound (LIS) surface water was studied by the shaking test. The LIS surface water was at the Haque Basin inside the Little Neck Bay on a clear and sunny summer day, 24 August 2020 at 11:00 a.m. Under exposure to the $365 \mathrm{~nm}$ wavelength UV light, the shaking test was completed by treating $1 \mathrm{~mL}$ of LIS surface water with $5 \mathrm{mg}$ of $\mathrm{MS}_{-} \mathrm{TiO}_{2}-10$ for a total of $30 \mathrm{~min}$. The cultivable bacteria in the water after 5, 10, 15, 20, 25, and $30 \mathrm{~min}$ treatments were observed by placing $12 \mu \mathrm{L}$ of each treated water sample on a nutrient agar plate. A control LIS surface water sample was treated with solely UV light for comparison purposes.

\section{Results and Discussion}

\subsection{Characterization}

To obtain the bifunctional magnetic $\mathrm{MS}^{-\mathrm{TiO}_{2}}$ antimicrobial nanocomposite, a threestep synthetic procedure was employed: (1) the $\mathrm{Fe}_{3} \mathrm{O}_{4}$ nanoparticles were first obtained by mixing stoichiometric amounts of $\mathrm{FeCl}_{3}$ and $\mathrm{FeCl}_{2}$ aqueous solutions followed by dropwise addition of an ammonia solution over 5-8 min [27]. (2) The MS was prepared using a previously reported eco-friendly procedure [27]. The as-prepared $\mathrm{Fe}_{3} \mathrm{O}_{4}$ nanoparticles were coated with an ultrafine silica layer using only water as the solvent, tetraethyl orthosilicate (TEOS) as the silica source, and ammonia as the catalyst. The procedure required no use of alcohol, stabilizers, or elevated temperature, providing substantial advantages in terms of simplicity, safety, material cost, and environmental impact relative to the conventional Stober methods. This $\mathrm{SiO}_{2}$ coating not only gave rise to the product's resistance to oxidation, as demonstrated in our earlier work [27], but also a surface that was rich in silanol ( $\mathrm{Si}-\mathrm{OH})$ groups to bind with $\mathrm{TiO}_{2}$. It also negated the negative effect of iron oxide on the photocatalytic capability of $\mathrm{TiO}_{2}$ [28]. (3) Finally, the $\mathrm{TiO}_{2}$ particles were incorporated onto the MS core-shell surface via a sol-gel process based on hydrolysis and condensation of titanium isopropoxide (TIPP). The reaction was carried out at a pH of 3, 7, and 10 to investigate how $\mathrm{pH}$ would influence the $\mathrm{TiO}_{2}$ upload. $\mathrm{The}_{\mathrm{TiO}}$ in the as-prepared samples tended to be mostly amorphous. Annealing was necessary to encourage the formation of the anatase phase, which serves as the photoactive antimicrobial agent. To avoid possible phase changes for magnetite core at temperatures upwards of $400{ }^{\circ} \mathrm{C}$, annealing was completed at $300{ }^{\circ} \mathrm{C}$ for 1 week $[31,37,38]$.

To investigate the effect of annealing on the $\mathrm{TiO}_{2}$ anatase phase formation, the MS$\mathrm{TiO}_{2}-10$ nanocomposite prepared using $50 \mathrm{mg}$ of $\mathrm{MS}$ nanoparticles and the corresponding $\mathrm{TiO}_{2}-10$ control sample, both as-prepared and annealed (at $300^{\circ} \mathrm{C}$ ), were characterized by XRD. As shown in Figure 1a, the as-prepared $\mathrm{TiO}_{2}$ was mostly amorphous with a weak diffraction pattern due to the presence of a small degree of anatase crystalline phase, as expected. After annealing the sample at $300{ }^{\circ} \mathrm{C}$ for 7 days, a drastic increase in the intensity of the anatase peaks was observed, indicating that annealing induced a high degree of anatase crystalline phase (see Figure 1b). The anatase phase produced a series of diffraction peaks at the position peaks of $25.5^{\circ}(101), 38.0^{\circ}(004), 48.2^{\circ}(200), 53.8^{\circ}(105), 55.2^{\circ}(211)$, $62.6^{\circ}(204), 68.5^{\circ}(116), 70.1^{\circ}(220), 74.8^{\circ}(215)$, and $82.5^{\circ}$ (224) [39]. No peaks characteristic of the rutile phase were observed, which, if present, would be of a very small amount [40]. The average crystal size, assuming spherical shape, was determined to be about $10.5 \mathrm{~nm}$ from the full width at half-maximum (FWHM) of the (101) peak of the XRD pattern using Scherrer's formula, $D=\frac{k \lambda}{\gamma \cos \theta}$, where $D$ is the crystal size in $\mathrm{nm}, \lambda$ is the wavelength of 
the radiation ( $0.15406 \mathrm{~nm}$ for $\mathrm{Cu} \mathrm{K} \alpha$ radiation), $k$ is a constant equal to $0.89, \gamma$ is the peak width at a half-maximum intensity and $\theta$ is the peak position [30]. The XRD pattern of MS- $\mathrm{TiO}_{2}-10$ samples is shown in Figure 2. All peaks in Figure 2a were indexed as peaks of

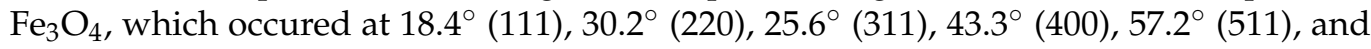
$62.9^{\circ}$ (440) [41]. No specific peaks of $\mathrm{SiO}_{2}$ were detected due to the amorphous nature of the coating. Broad but observable peaks due to anatase at $25.5^{\circ}(101), 48.2^{\circ}(200)$, and $74.8^{\circ}(215)$ were detected, as a result of an increased amount of anatase phase, induced by annealing, as evident in the XRD graphs of the $\mathrm{TiO}_{2}-10$ samples as shown in Figure $2 b$ and HRTEM images in Figure 3a,b. The broad peaks suggest that these anatase crystallites formed on the magnetic MS cores were very small. Annealing at $300{ }^{\circ} \mathrm{C}$ did not transform magnetite to hematite $\left(\alpha-\mathrm{Fe}_{2} \mathrm{O}_{3}\right)$ since no peaks due to the latter appeared in the XRD pattern [42].

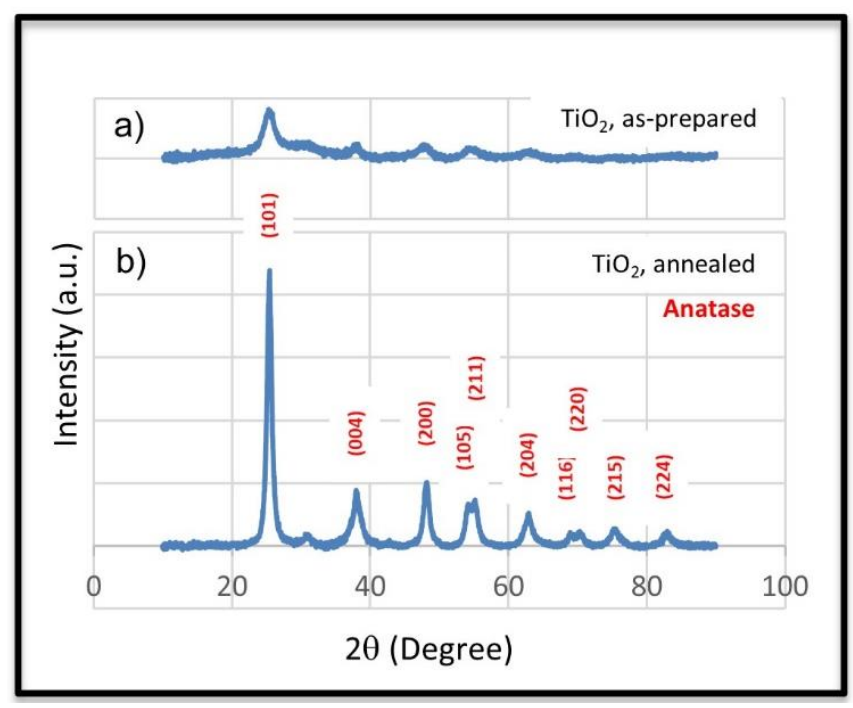

Figure 1. XRD pattern of $\mathrm{TiO}_{2}-10$ : (a) as-prepared, and (b) annealed at $300{ }^{\circ} \mathrm{C}$.

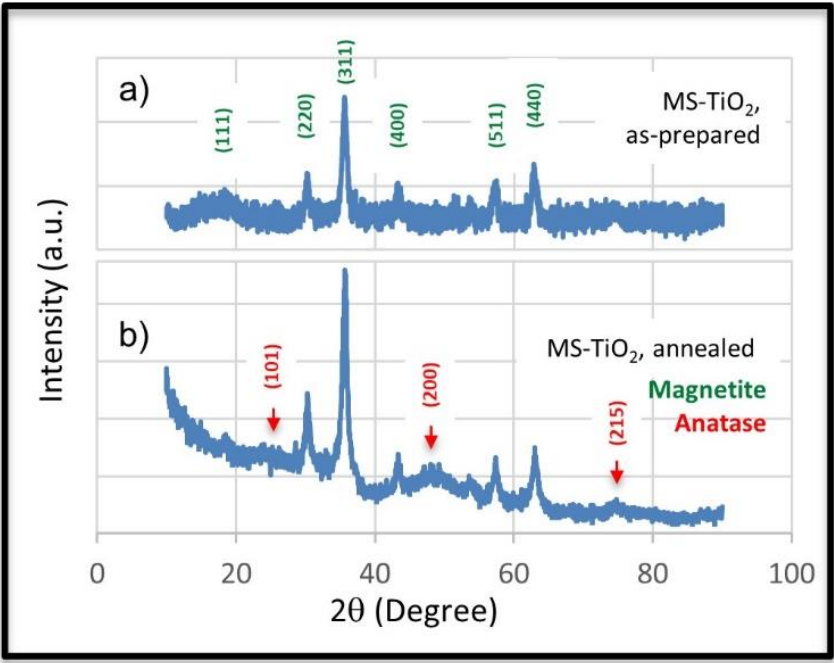

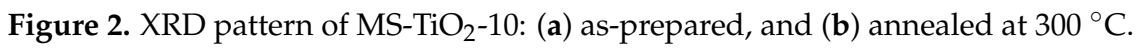




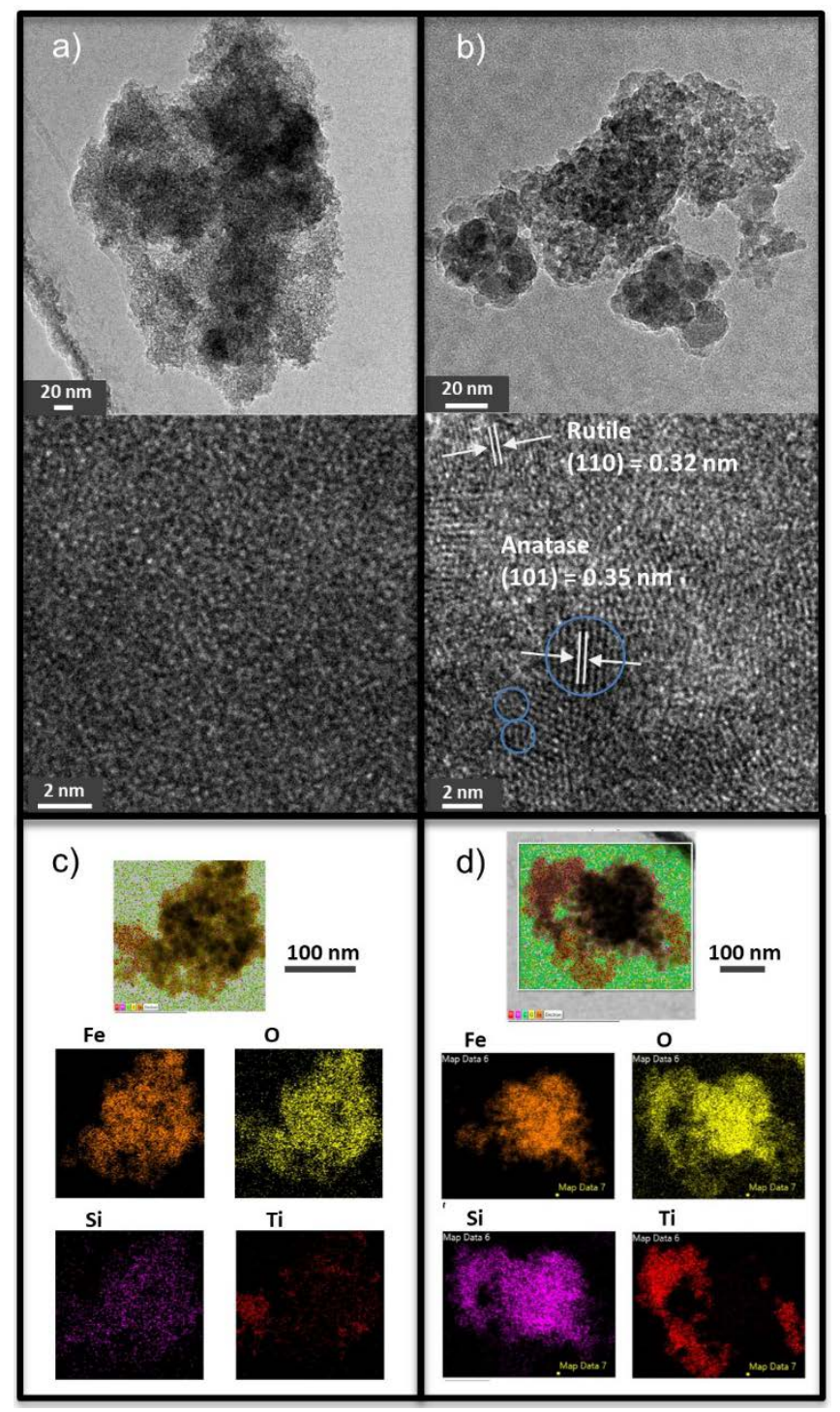

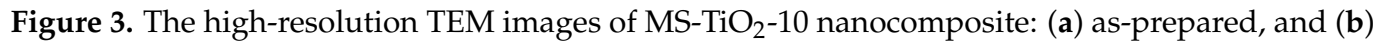
annealed at $300{ }^{\circ} \mathrm{C}$. Blue circles show examples of some small anatase crystallites. The EDS elemental mapping of the $\mathrm{MS}-\mathrm{TiO}_{2}-10$ nanocomposite samples: (c) as-prepared, and (d) annealed at $300{ }^{\circ} \mathrm{C}$.

The structural morphology and elemental maps of $\mathrm{MS}^{-} \mathrm{TiO}_{2}$ nanocomposites were observed through high-resolution transmission electron microscopy (HRTEM) and energy-

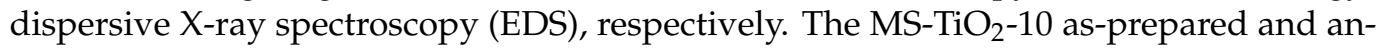
nealed samples were imaged using an e-beam of $200 \mathrm{keV}$. The high-resolution images, shown in Figure $3 a, b$, revealed the aggregations of many small magnetic particles into large ones approximately 100-300 $\mathrm{nm}$ in size. The high magnification TEM images showed that the as-prepared sample (Figure 3a) was mostly amorphous that lacked lattice fringes in their images, while the annealed sample (Figure $3 b$ ) was highly crystalline, whose images contained large portions of lattice fringes. The HRTEM image in Figure $3 \mathrm{~b}$ reveals that most of the crystallites were anatase and very small, about $2-5 \mathrm{~nm}$ in size. The fringe spacing parallel was estimated to be $0.35 \mathrm{~nm}$, consistent with the d value of (101) lattice spacing of anatase phase [43]. The image also provides evidence for the presence of a very small amount of rutile phase. The interplanar space of $0.32 \mathrm{~nm}$ was observed, which corresponded to the (110) plane of the rutile phase [43]. These results agreed well with those of the XRD and showed that annealing of $\mathrm{MS}^{-\mathrm{TiO}_{2}}$ at $300^{\circ} \mathrm{C}$ transformed amorphous $\mathrm{TiO}_{2}$ coated on the magnetic MS cores to a high degree of anatase crystallites, which were

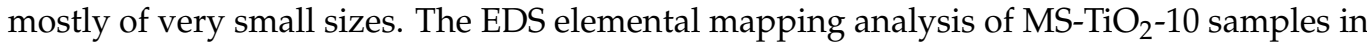


Figure 3c,d clearly proves the presence of the element titanium, in addition to elements Fe, $\mathrm{O}$, and $\mathrm{Si}$. It also showed that where titanium was found, all other elements were present, confirming that titanium was truly attached to the surface of the MS magnetic core-shell structure. It can also be seen that titanium, although spatially distributed throughout the sample, differed in intensity in different areas, suggesting that variations in composition from particle to particle are expected. The EDS elemental data for $\mathrm{MS}-\mathrm{TiO}_{2}$ synthesized under different $\mathrm{pH}$ using $50 \mathrm{mg}$ of $\mathrm{MS}$ are provided in Table 1. The results showed that the $\mathrm{pH}$ that produced the greatest relative growth of $\mathrm{TiO}_{2}$ onto the silica-coated magnetite particles was a $\mathrm{pH}$ of 10 , which gave a Ti element content of $12.6 \mathrm{wt} . \%$. This value, over double either of the other two nanocomposites (one at $5.6 \mathrm{wt}$.\% with a neutral condition and another $2.5 \mathrm{wt}$ \% using a $\mathrm{pH} 3$ reaction medium), would potentially produce the greatest amount of anatase phase through proper annealing conditions, and thus the greatest antimicrobial potency. The presence of an acid or base catalyst in the sol-gel solution was reported to influence the hydrolysis and condensation rates of titanium alkoxide [36]. At low $\mathrm{pH}$ of 3, the hydrolysis reaction was catalyzed by the presence of protons through protonation of the alkoxy group. However, at the same time, protonation of the Ti-OH groups inhibited the nucleophilic attack on $\mathrm{Ti}$ in other clusters, retarding the condensation reaction. The slow condensation rate impeded the formation of the $\mathrm{TiO}_{2}$ network, thus its incorporation into the MS nanocomposite. On the other hand, in alkaline conditions, besides the shift of the primary nucleophile from water to hydroxide, strong nucleophiles were produced via deprotonation of the $\mathrm{Ti}-\mathrm{OH}$ groups, resulting in an increased condensation rate. The rapid reaction led to the $\mathrm{TiO}_{2}$ network formation. The silica surface of the nanocomposite, when subject to an alkaline condition, also deprotonated into negatively charged $\mathrm{Si}^{-} \mathrm{O}^{-}$sites that facilitated the attachment of Ti clusters and their subsequent network formation. The amount of element titanium incorporated into the magnetic nanocomposite under a $\mathrm{pH}$ of 10 was found to generally increase from $10 \pm 4$ to $15 \pm 4 \mathrm{wt} \%$ as the MS amount employed decreased from $70 \mathrm{mg}$ to $12.5 \mathrm{mg}$, based on the EDS measurements. If not specified, the results reported here are based on the samples prepared using $50 \mathrm{mg}$ of MS.

Table 1. Element weight percent (wt. $\%$ ) by EDS for $\mathrm{MS}_{-} \mathrm{TiO}_{2}$ prepared under different $\mathrm{pHs}$.

\begin{tabular}{cccc}
\hline Element & MS-TO $\mathbf{2}-\mathbf{3}$ & MS-TO $_{\mathbf{2}} \mathbf{- 7}$ & MS-TO $_{\mathbf{2}} \mathbf{- 1 0}$ \\
\hline $\mathrm{Fe}$ & 50.2 & 31.5 & 42.0 \\
$\mathrm{O}$ & 42.1 & 58.3 & 40.7 \\
$\mathrm{Si}$ & 5.3 & 4.6 & 4.8 \\
$\mathrm{Ti}$ & 2.5 & 5.6 & 12.6 \\
\hline
\end{tabular}

The FTIR-ATR spectra of the as-prepared magnetic nanocomposite samples, $\mathrm{MS}-\mathrm{TiO}_{2}-3$, MS- $\mathrm{TiO}_{2}-7$, and $\mathrm{MS}-\mathrm{TiO}_{2}-10$, were similar, and the spectrum of $\mathrm{MS}-\mathrm{TiO}_{2}-10$ is shown in Figure $4 \mathrm{a}$. The absorption peak at around $540 \mathrm{~cm}^{-1}$ was assigned to the $\mathrm{Fe}-\mathrm{O}$ vibration, a characteristic peak of $\mathrm{Fe}_{3} \mathrm{O}_{4}$ that is observed for all magnetic nanocomposite samples. A broad band at around $1060 \mathrm{~cm}^{-1}$ with a visible high-frequency shoulder at around $1160 \mathrm{~cm}^{-1}$, appeared in all spectra [27]. These bands, assigned to the asymmetric Si-O-Si linkage, provided spectroscopic evidence of the presence of $\mathrm{SiO}_{2}$ in these samples, especially the formation of a core-shell structure in the MS sample. The additional absorption peaks at around $900 \mathrm{~cm}^{-1}$ were assigned to the stretching vibrations of $\mathrm{Si}-\mathrm{OH}$ [27]. Incorporating $\mathrm{TiO}_{2}$ into the MS nanocomposite did not result in noticeable new absorption peaks in the IR spectra. This was attributed to (1) relatively small added $\mathrm{TiO}_{2}$ amounts as shown by EDS data; (2) generally weak IR absorption of $\mathrm{TiO}_{2}$, as shown in Figure $2 \mathrm{~b}$ by the commercial $\mathrm{TiO}_{2}$ IR spectrum; and (3) the overlap of the Ti-O-Ti peaks with those of $\mathrm{Fe}-\mathrm{O}$ in the $600-800 \mathrm{~cm}^{-1}$ region, as shown in Figure $2 \mathrm{a}, \mathrm{b}$. To understand the effect of $\mathrm{pH}$ during the synthesis on the structures and upload of $\mathrm{TiO}_{2}$, the $\mathrm{TiO}_{2}$ control samples without the presence of MS were prepared, and their FTIR spectra, along with those of the TIPP precursor and the commercial $\mathrm{TiO}_{2}$ (anatase) sample, were shown in Figure $4 \mathrm{~b}$. The characteristic Ti-O-Ti peaks can be seen to occur at around $600-800 \mathrm{~cm}^{-1}$ [44]. Peaks 
around $3000 \mathrm{~cm}^{-1}$ and ranging from 1390 to $1490 \mathrm{~cm}^{-1}$ relate to $-\mathrm{CH}_{2}$ - or $-\mathrm{CH}_{3}[36,44,45]$. It can be seen that the as-prepared $\mathrm{TiO}_{2}$ under different $\mathrm{pH}$ conditions and after reacting for $32 \mathrm{~h}$ resembled the mixture of spectra of the titanium isopropoxide precursor and the commercial $\mathrm{TiO}_{2}$. Compared to the spectrum of TIPP, a new peak at $1620 \mathrm{~cm}^{-1}$ appeared. This peak, relating to Ti-OH [36] and resulting from the hydrolysis, was the greatest for $\mathrm{TiO}_{2}$ prepared under the acidic condition. As $\mathrm{pH}$ increased, peaks due to $-\mathrm{CH}_{2}-$ or $-\mathrm{CH}_{3}$ and $\mathrm{Ti}-\mathrm{OH}$ all decreased relative to that attributed to the Ti-O-Ti mode, although the spectral differences for the products prepared under neutral and basic conditions were small. This suggests that $\mathrm{TiO}_{2}$ obtained at $\mathrm{pH} 10$ contained the least amount of residual carbon and hydroxyl groups, originating from the unreacted alkyl groups and incomplete condensation, respectively. Since the degree of completion of the $\mathrm{TiO}_{2}$ reaction increased as $\mathrm{pH}$ increased, the amount of $\mathrm{TiO}_{2}$ bonded to the MNPs would be expected to increase with increasing $\mathrm{pH}$. This was consistent with the results from the EDS measurements.

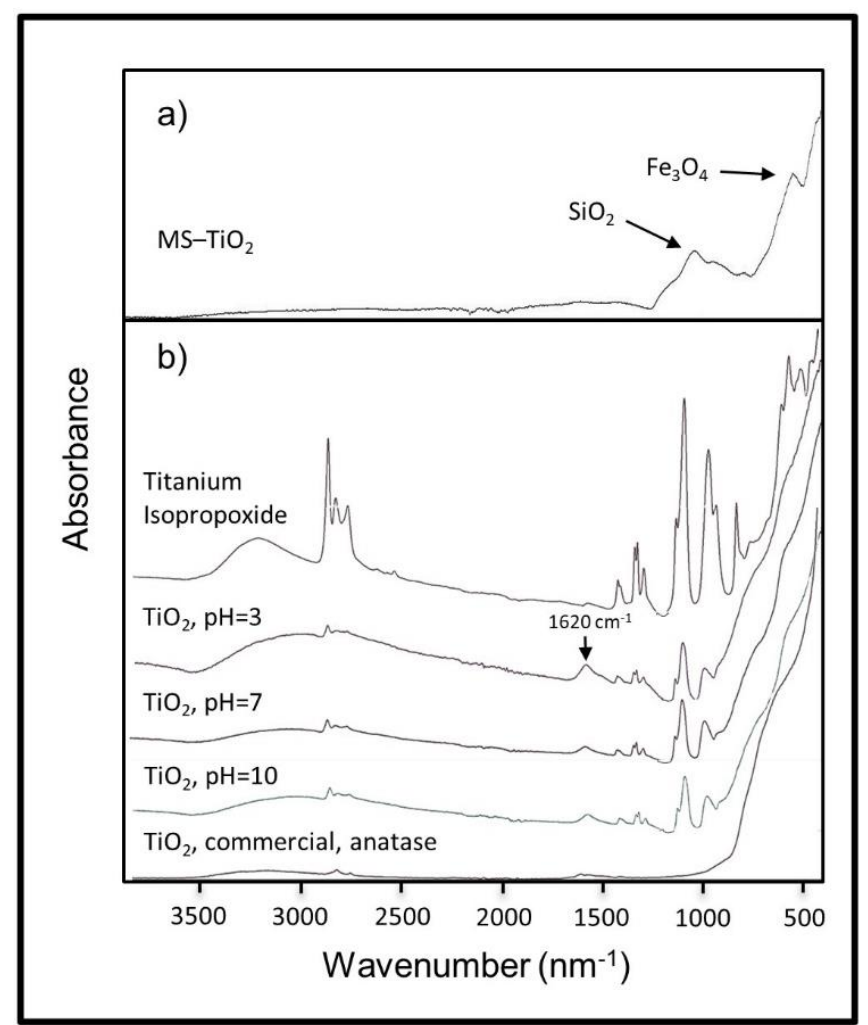

Figure 4. The FTIR spectra of (a) as-synthesized $\mathrm{MS}-\mathrm{TiO}_{2}$ and (b) the $\mathrm{TiO}_{2}$ control samples prepared under varied $\mathrm{pH}$ conditions without the presence of MS, along with the TIPP precursor and the commercial $\mathrm{TiO}_{2}$ (anatase) sample.

Magnetic behaviors of the related nanocomposites are shown in Figure 5. The measurements were conducted at room temperature using a VSM in an external magnetic field ranging from -10 to $+10 \mathrm{MG}$. The magnetization versus applied field curves showed no hysteresis and was completely reversible for all samples. Neither coercivity nor remanence was observed, indicating the superparamagnetic nature of these magnetic nanocomposites. The saturation magnetization value, $\mathrm{M}_{\mathrm{S}}$, extracted from the corresponding hysteresis loop at $\pm 10 \mathrm{MG}$ for the MS nanocomposite, was $59 \mathrm{emu} / \mathrm{g}$. The $\mathrm{M}_{\mathrm{S}}$ value decreased to

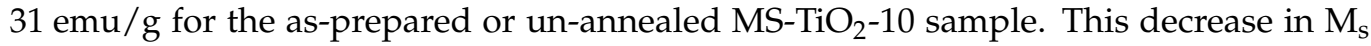
was attributed to the increased weight contribution of the nonmagnetic $\mathrm{TiO}_{2}$ and inner silica shell surrounding the magnetic magnetite cores. Annealing the $\mathrm{MS}_{-} \mathrm{TiO}_{2}-10$ sample at $300{ }^{\circ} \mathrm{C}$ for 1 week produced a $\mathrm{M}_{\mathrm{s}}$ value of $33 \mathrm{emu} / \mathrm{g}$, similar to that of the un-annealed counterpart. The fact that annealing did not reduce the $\mathrm{M}_{\mathrm{s}}$ value of the nanocomposite provided strong evidence that the thin silica coating successfully prevented the $\mathrm{Fe}_{3} \mathrm{O}_{4}$ 
core from being oxidized to maghemite, hematite, and/or goethite forms, which would be much less magnetic. For instance, annealing magnetite at $300^{\circ} \mathrm{C}$ for $1 \mathrm{~h}$ was reported to have reduced the $\mathrm{M}_{\mathrm{s}}$ by $35 \%$ due to the formation of maghemite [46]. The lowered $\mathrm{M}_{\mathrm{s}}$ for MS- $\mathrm{TiO}_{2}-10$ compared to $\mathrm{MS}-\mathrm{TiO}_{2}$, however, did not affect the instantaneous separation of the nanocomposite from treated water using a magnet, as demonstrated in Figure 5. Upon shaking, the nanocomposite particles quickly dispersed in water, and then instantaneously attracted to a magnet when a magnet was placed nearby, indicating they could be readily separated from the aqueous solution by the magnet. This cycle was repeated countless times without observable changes in their behaviors. The superparamagnetic behavior and high $\mathrm{M}_{\mathrm{S}}$ value are very desirable for these particles' easy recovery and repeated use as an effective green strategy for water treatment applications.

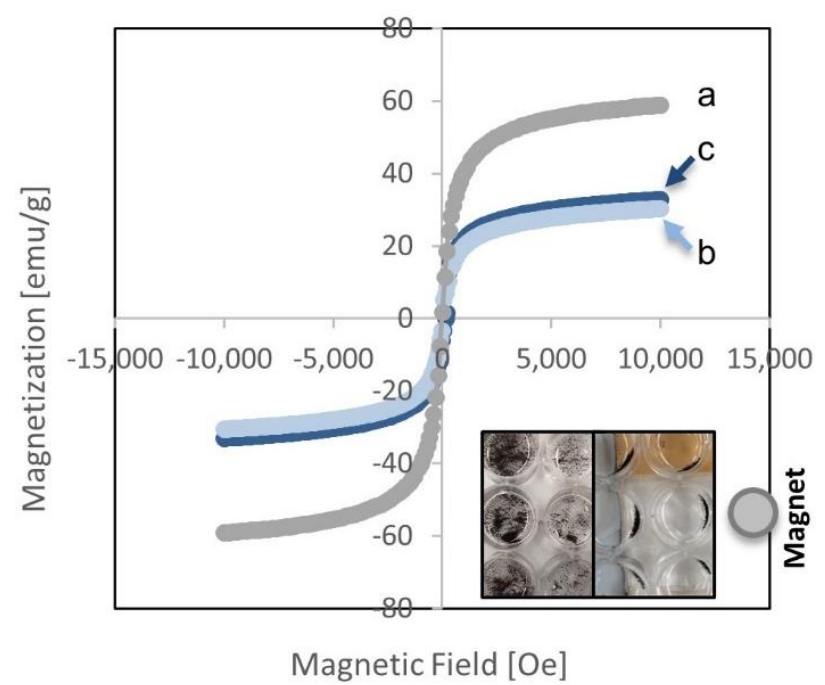

Figure 5. Magnetization curves for (a) MS, (b) as-prepared $\mathrm{MS}-\mathrm{TiO}_{2}-10$, and (c) annealed $\mathrm{MS}-\mathrm{TiO}_{2}-10$ nanocomposites, measured using a VSM at room temperature. The insert shows the instantaneous

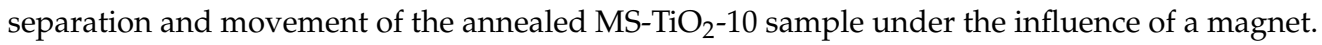

\subsection{Antimicrobial Experiments}

\subsubsection{Shaking Tests}

To test the antimicrobial properties of the magnetic nanocomposite, $30 \mathrm{mg}$ of each of the six samples, $\mathrm{MS}-\mathrm{TiO}_{2}-3, \mathrm{MS}-\mathrm{TiO}_{2}-7$, and $\mathrm{MS}-\mathrm{TiO}_{2}-10$, as-prepared and annealed, was placed in $1 \mathrm{~mL}$ of an E. coli suspension of $10^{4} \mathrm{CFU} / \mathrm{mL}$. The samples contained 2.5, 5.6,

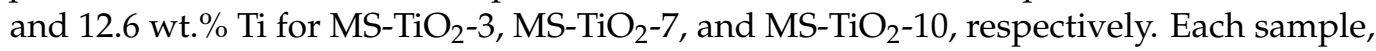
being continuously agitated in the suspension, was tested over a $70 \mathrm{~min}$ period under exposure to a $365 \mathrm{~nm}$ wavelength ultraviolet light. A $6 \mu \mathrm{L}$ sample was taken at $10 \mathrm{~min}$ increments each. This process was repeated every 10 minutes. Throughout the experiment, a control plate was created where E. coli suspension was treated solely with UV light for comparison purposes. The agar plates containing sampled suspensions were incubated for $24 \mathrm{~h}$ at $37^{\circ} \mathrm{C}$. The results, in terms of minimum inhibitory time, $\mathrm{MIT}_{98}$, and \% bacteria reduction after $70 \mathrm{~min}$ treatment, are summarized in Table 2, along with some typical plate outcomes, as shown in Figure 6. The $\mathrm{MIT}_{98}$ was defined as the minimum time observed for $98 \%$ bacterial count reduction after $24 \mathrm{~h}$ incubation at $37^{\circ} \mathrm{C}$. 
Table 2. The antimicrobial activities of the as-prepared and annealed $\mathrm{MS}^{-} \mathrm{TiO}_{2}$ nanocomposites under $365 \mathrm{~nm}$ UV light for treating a $10^{4} \mathrm{CFU} / \mathrm{mL}$ E. coli suspension.

\begin{tabular}{|c|c|c|c|c|}
\hline & \multicolumn{2}{|c|}{ As-Prepared } & \multicolumn{2}{|c|}{ Annealed at $300^{\circ} \mathrm{C}$} \\
\hline & $\mathrm{MIT}_{98}, \min$ & $\%$ Reduction at $70 \mathrm{~min}$ & $\mathrm{MIT}_{98}, \mathrm{~min}$ & $\%$ Reduction at $70 \mathrm{~min}$ \\
\hline Control (blank) & $50 \pm 5$ & $>98$ & $50 \pm 5$ & $>98$ \\
\hline 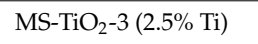 & $>70$ & $80 \pm 5$ & $25 \pm 5$ & $>98$ \\
\hline $\mathrm{MS}^{-\mathrm{TiO}_{2}-7}(5.6 \% \mathrm{Ti})$ & $>70$ & $75 \pm 5$ & $65 \pm 5$ & $>98$ \\
\hline 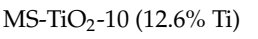 & $>70$ & $86 \pm 5$ & $25 \pm 5$ & $>98$ \\
\hline
\end{tabular}

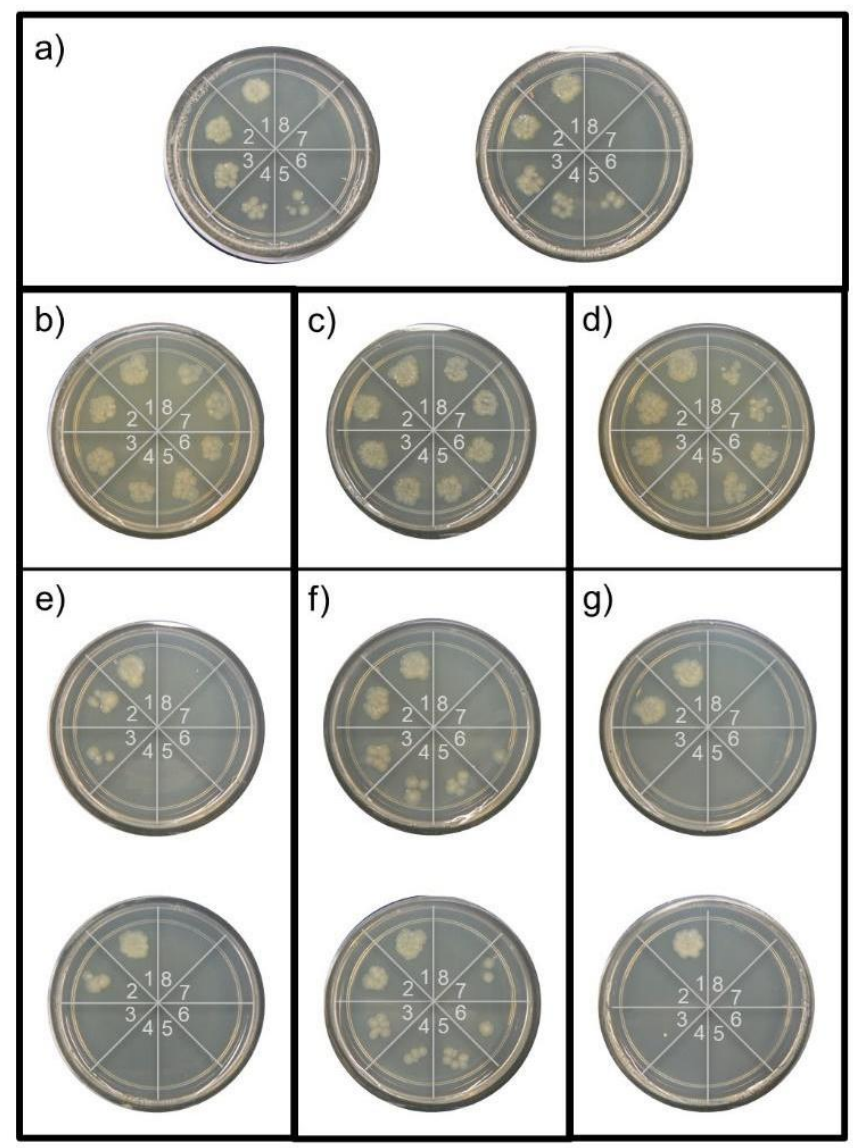

Figure 6. Sample plate results illustrating the antimicrobial activities under $365 \mathrm{~nm}$ UV light (a) without the presence of nanocomposite, and with the presence of the $30 \mathrm{mg} / \mathrm{mL}$ of (b) as-prepared

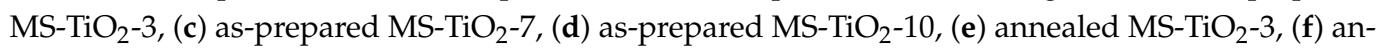
nealed $\mathrm{MS}-\mathrm{TiO}_{2}-7,(\mathrm{~g})$ annealed $\mathrm{MS}-\mathrm{TiO}_{2}-10$ nanocomposite against $E$. coli in a suspension containing $10^{4} \mathrm{CFU} / \mathrm{mL}$. Note: 1 = untreated, 2, 3, 4, 5, 6, 7, 8 = after 10, 20, 30, 40, 50, 60, 70 min treat-

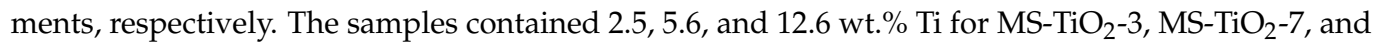
MS- $\mathrm{TiO}_{2}-10$, respectively.

The control plates in Figure 6a show that the UV treatment of E. coli in the $10^{4} \mathrm{CFU} / \mathrm{mL}$ suspension with $365 \mathrm{~nm}$ wavelength, without the presence of the nanocomposite, had a $\mathrm{MIT}_{98}$ of $50 \mathrm{~min}$. Although there was a clear bacterial reduction in each plate in Figure $6 \mathrm{~b}$ with the addition of the as-prepared $\mathrm{MS}-\mathrm{TiO}_{2}$ composite samples, regardless of the synthetic $\mathrm{pH}$ conditions, the reduction rate was hindered comparing to that of the control plates since bacterial growth up to and through the 70 min treatment was observed with a MIT $_{98}$ of more than $70 \mathrm{~min}$. The retardation in reduction rate is attributed to (1) the shielding effect of the black nanocomposite particles and (2) the inadequate anatase crystalline phase present in the nanocomposite. For UV light treatment, the bacteria need to be directly exposed to the light wave. The presence of the added nanoparticles blocked this light 
energy from reaching, and therefore damaging or inactivating, the bacteria cells, allowing bacteria to persist longer than those in the control samples under the same treatment conditions. A similar shielding effect was also observed by Alvarez et al. [28], who studied the photodegradation of acetaminophen (Ac) in an aqueous solution under UV illumination. The authors found that Ac was partially photolyzed under UV illumination alone, but the photodegradation was slowed in the presence of magnetite nanoparticles. The reduction in photodegradation rate was attributed to the shielding of Ac from the direct light by the suspended nanoparticles, which did not possess catalytic activity towards Ac degradation. As shown in the X-ray diffraction and HRTEM results, the as-prepared nanocomposites were largely amorphous with a very low degree of anatase amount, which was unable to generate enough antimicrobial effect to compensate for the lost UV-induced inactivation effect due to shielding. The estimated percent reductions in the bacterial count were $80 \%$, $75 \%$, and $86 \%$ after $70 \mathrm{~min}$ treatment of the $10^{4} \mathrm{CFU} / \mathrm{mL}$ E. coli suspensions with the as-prepared $\mathrm{MS}_{-} \mathrm{TiO}_{2}-3, \mathrm{MS}-\mathrm{TiO}_{2}-7$, and $\mathrm{MS}-\mathrm{TiO}_{2}-10$ nanocomposites, respectively. The $\mathrm{TiO}_{2}$ anatase phase is known to be the effective phase that provides antimicrobial efficacy. Annealing the nanocomposites at $300{ }^{\circ} \mathrm{C}$ for a week resulted in a large increase in the anatase amount, which greatly enhanced the nanocomposites' antimicrobial efficacies as tested against the E. coli bacteria in the $10^{4} \mathrm{CFU} / \mathrm{mL}$ suspensions. However, annealing $\mathrm{TiO}_{2}$ at $300{ }^{\circ} \mathrm{C}$ has been shown to produce different degrees of anatase crystallinity for the samples prepared under different $\mathrm{pH}$ conditions [36]. Based on x-ray diffraction peak intensities, Simonsen et al. [36] reported that the $\mathrm{TiO}_{2}$ sample prepared at a $\mathrm{pH}$ of 3 produced the greatest amount of anatase crystals, with their diffraction peak intensity being 6.4 and 1.3 times higher than those of the samples prepared at a $\mathrm{pH}$ of 7 and $\mathrm{pH}$ of 10, respectively. These results were consistent with the antimicrobial properties of our $\mathrm{MS}_{-} \mathrm{TiO}_{2}$ nanocomposites prepared under the respective $\mathrm{pH}$ conditions. For the nanocomposite prepared at a $\mathrm{pH}$ of 7 , it can be seen that although the $\mathrm{MIT}_{98}$ was improved to $65 \mathrm{~min}$, it was still $15 \mathrm{~min}$ slower than that of the control sample. This was likely due to the relative (1) small amount of $\mathrm{TiO}_{2}(5.6 \mathrm{wt} . \% \mathrm{Ti})$ incorporated into the nanocomposite and (2) slow anatase conversion rate upon annealing [36]. Consequently, there was still not enough anatase to generate the antimicrobial effect superior to that by UV radiation alone. For the nanocomposites prepared under $\mathrm{pH}$ of 3 and 10 conditions, the $\mathrm{MIT}_{98}$ were greatly improved to $25 \mathrm{~min}$, which became $25 \mathrm{~min}$ faster than that of the control samples. Synthesizing the nanocomposite under a $\mathrm{pH}$ of 10 conditions gave the highest $\mathrm{TiO}_{2}$ content (12.6 wt. $\left.\% \mathrm{Ti}\right), 2-5$ times higher than those prepared under neutral and acidic conditions. Subsequent annealing allowed a relatively large amount of anatase phase to form that resulted in a significantly enhanced bactericidal effect on E. coli under a $365 \mathrm{~nm}$ UV light. Although the synthetic condition of $\mathrm{pH} 3$ incorporated the least amount of $\mathrm{TiO}_{2}$ ( 2.5 wt.\% Ti) into the nanocomposite, its $\mathrm{TiO}_{2}$ crystalized easiest into the anatase phase [36], leading to its evidently boosted antimicrobial effectiveness. Since the synthetic condition of $\mathrm{pH}$ of 10 offered the optimal potential for incorporating the greatest amount of anatase into the magnetic nanocomposites, all additional antimicrobial studies were based on the samples prepared under a $\mathrm{pH}$ of 10.

The antimicrobial efficiency of $\mathrm{MS}_{-} \mathrm{TiO}_{2}-10$ as a function of the amount used was further assessed based on $\mathrm{MIT}_{98}$ measurements using the annealed nanocomposite samples containing $8.7 \mathrm{wt}$. \% Ti and treating an E. coli suspension of $3 \times 10^{4} \mathrm{CFU} / \mathrm{mL}$ under $365 \mathrm{~nm} \mathrm{UV}$ radiation. The results are shown in Table 3. Under the experimental conditions, the $365 \mathrm{~nm}$ UV light required $97 \mathrm{~min}$ to inhibit $98 \%$ of the $E$. coli in the suspension. It can be seen that increasing the nanocomposite amount did not result in an increased antimicrobial effect, which was once again largely attributed to the balance between the (1) shielding and (2) anatase content effects. As the nanocomposite amount increased, so did both the shielding and anatase content effects. However, while the latter decreased the $\mathrm{MIT}_{98}$, the former increased it. When the shielding effect outweighed the anatase content effect, the nanocomposite showed a longer $\mathrm{MIT}_{98}$, as illustrated in the case when $30 \mathrm{mg}$ of the nanocomposite was employed, which gave the $\mathrm{MIT}_{98}$ of $110 \mathrm{~min}$, about $13 \mathrm{~min}$ longer 
than that of the control. On the other hand, when the anatase effect predominated, the nanocomposite displayed a shorter $\mathrm{MIT}_{98}$, as in the case when $10 \mathrm{mg}$ of the nanocomposite was employed, which produced the $\mathrm{MIT}_{98}$ of $80 \mathrm{~min}$, about $17 \mathrm{~min}$ shorter than that of the control. It appeared that $1 \mathrm{mg}$ of nanocomposite provided a condition allowing the two effects to nearly offset each other and yielding a $\mathrm{MIT}_{98}$ of $93 \mathrm{~min}$, similar to that of $365 \mathrm{~nm}$ UV light without the presence of the nanocomposite. Additionally, increasing the amount of nanocomposite may also lead to increased particle aggregation due to combined van der Waals and magnetic forces. Small $\mathrm{MS}-\mathrm{TiO}_{2}$ nanoparticles with a large surface area are favored since they are better dispersed, more effectively exposed to UV light, water, and dissolved oxygen, and thus possess greater photocatalytic activities and bactericidal potency [47]. An increased amount of magnetic nanocomposite particles would therefore worsen aggregation, further undermining their effectiveness as biocides besides producing an increased shielding effect.

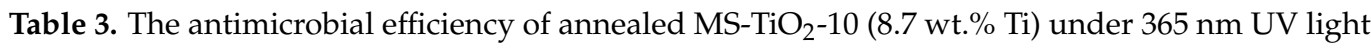
based on minimum inhibitory time $\mathrm{MIT}_{98}$ measurements for treating a $3 \times 10^{4} \mathrm{CFU} / \mathrm{mL}$ E. coli suspension.

\begin{tabular}{ccccc}
\hline \multirow{2}{*}{ Trial } & \multicolumn{4}{c}{ MIT $_{\mathbf{9 8}}, \mathbf{m i n}$} \\
\cline { 2 - 5 } & Control & $\mathbf{3 0} \mathbf{~ m g}$ & $\mathbf{1 0} \mathbf{~} \mathbf{g}$ & $\mathbf{1 ~} \mathbf{~ g}$ \\
\hline 1 & 90 & 100 & 80 & 90 \\
2 & 110 & 110 & 70 & 90 \\
3 & 90 & 120 & 90 & 100 \\
Average & $97 \pm 9$ & $110 \pm 8$ & $80 \pm 8$ & $93 \pm 8$ \\
\hline
\end{tabular}

\subsubsection{Reusability Tests}

To be competitive in the water treatment market, in theory, the magnetic nanocomposites should be infinitely reusable. The oxidation of iron(II) ions in magnetite has been mitigated with a silica coating on the particle. A unique characteristic of the $\mathrm{TiO}_{2}$ semiconductor is that it is regenerative. Every electron released from the valence band to the conduction band is replaced by the environment around it. Therefore, all components should be theoretically reusable and therefore "green" [48]. To verify the reusability of the nanocomposite, a quantity of $5 \mathrm{mg}$ of annealed $\mathrm{MS}^{-} \mathrm{TiO}_{2}-10$ containing $8.7 \mathrm{wt} . \%$ Ti was repeatedly employed in treating $1 \mathrm{~mL}$ of $10^{4} \mathrm{CFU} / \mathrm{mL}$ E. coli suspensions for three cycles. Each treatment, under the $365 \mathrm{~nm}$ UV light exposure, was $21 \mathrm{~min}$ long, and $6 \mu \mathrm{L}$ suspension sampling was completed at 3 min intervals. After 21 min exposure and shaking, the E. coli inactivation, induced by $365 \mathrm{~nm}$ UV light only, was found to be $70 \pm 3 \%$. The presence of $5 \mathrm{mg}$ of $\mathrm{MS}_{-} \mathrm{TiO}_{2}-10$ had increased the bactericidal rate to $88 \pm 4 \%$, demonstrating a more than $25 \%$ improvement. The agar plate results for one control and one sample used for three repeated treatments are shown in Figure 7. It can be seen that, with a standard deviation within $\pm 2 \%$ (based on triplicate measurements) for the E. coli reduction rates, the repeated use, up to three cycles, resulted in little change in the nanocomposite' antimicrobial capability. The easy recoverability and excellent reusability potential of $\mathrm{MS}^{-} \mathrm{TiO}_{2}-10$ make the nanocomposite very attractive, especially in large-scale applications, since they greatly reduce material cost and effectively minimize secondary pollution relating to the disposal of used materials. 


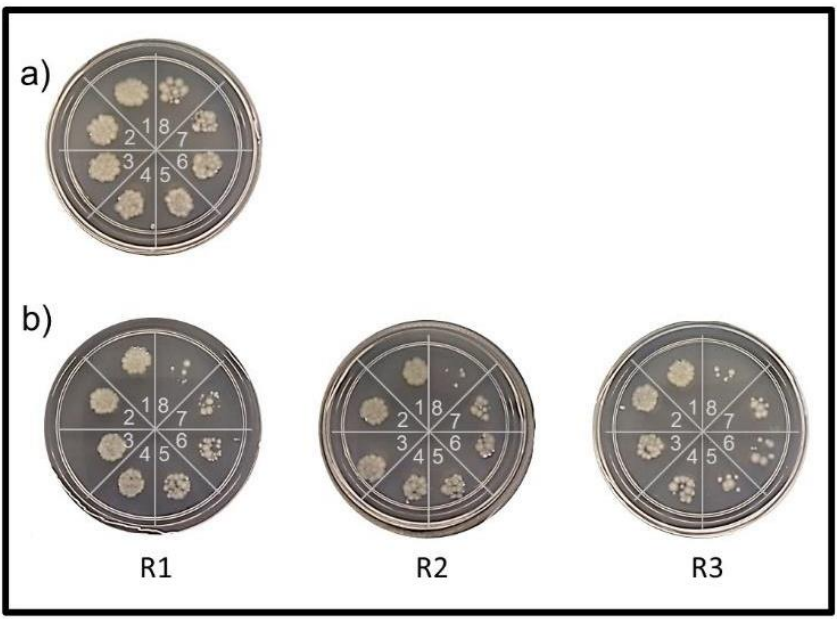

Figure 7. Reusability was tested by repeating $21 \mathrm{~min}$ treatment of $10^{4} \mathrm{CFU} / \mathrm{mL}$ E. coli culture using $5 \mathrm{mg} / \mathrm{mL}$ of annealed $\mathrm{MS}^{-\mathrm{TiO}_{2}-10}$ (8.7 wt.\% Ti) nanocomposite under $365 \mathrm{~nm}$ UV light. Agar plate results of (a) the control without the nanocomposite, and (b) the 3 repeated treatment cycles represented by R1, R2 and R3 with the nanocomposite. 1 = untreated, 2, 3, 4, 5, 6, 7, 8 = after 3, 6, 9, $12,15,18,21$ min treatments.

\subsubsection{Disinfection of Long Island Sound (LIS) Surface Water}

The feasibility of employing $\mathrm{MS}_{-} \mathrm{TiO}_{2}-10$ nanocomposite for disinfecting Long Island Sound (LIS) surface water was studied by performing the shaking test. The LIS surface water was obtained at the Haque Basin inside the Little Neck Bay on a clear summer day with a blazing sun, 24 August 2020 at 11:00 a.m. The colony counts of the LIS surface water were found to vary with seasons, with the summer water containing the most abundant cells and the winter water the least. The water sample obtained for this experiment was estimated to contain $500-5000 \mathrm{CFU} / \mathrm{mL}$, based on the bacterial counts on agar plates incubated at $37^{\circ} \mathrm{C}$ for $18 \mathrm{~h}$. The colonies of cultivable microbes were shown to be of a diversified nature with varied colors, shapes, sizes, and morphologies. Different types of bacteria may exhibit different levels of susceptibility to the bactericidal effect of $\mathrm{TiO}_{2}$. The LIS surface water had a $\mathrm{pH}$ of 7.98, turbidity of $0.0 \mathrm{NTU}$, and conductivity due to total dissolved solids of 26,000 $\mu \mathrm{S} / \mathrm{m}$. According to "Save the Sound" [49], the dissolved oxygen levels, chlorophyll a levels, Secchi Disk depth, and dissolved organic carbon levels measured at the station located in the Little Neck Bay in 2019 were $2.6 \mathrm{mg} / \mathrm{L}, 15.08 \mu \mathrm{g} / \mathrm{L}$, $1.13 \mathrm{~m}$, and $2.16 \mathrm{mg} / \mathrm{L}$, respectively. The averages of these values from 2008 to 2019 were $3.30 \pm 0.54 \mathrm{mg} / \mathrm{L}, 10.07 \pm 3.06 \mu \mathrm{g} / \mathrm{L}, 1.34 \pm 0.19 \mathrm{mg} / \mathrm{L}$, and $2.69 \pm 0.38 \mathrm{mg} / \mathrm{L}$, respectively. The reduction of bacteria in $1 \mathrm{~mL}$ of LIS surface water following interaction with a quantity of $5 \mathrm{mg}$ of MS-Ti-10 (8.7 wt.\% Ti), under the exposure of $365 \mathrm{~nm}$ UV light, was investigated by inoculating the treated water samples on agar plates. A $12 \mu \mathrm{L}$ sample was drawn every $5 \mathrm{~min}$ for a total of $30 \mathrm{~min}$ to observe the reduction in colony count in the treated water as a function of time. Duplicated agar plate results for treatment times equaling 0,20 min, $25 \mathrm{~min}$, and $30 \mathrm{~min}$ are shown in Figure 8. After $30 \mathrm{~min}$ exposure to

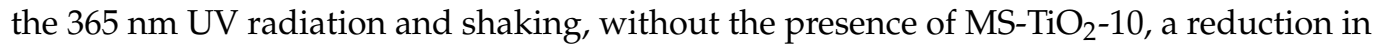
the bacteria count of the LIS surface water was not observed. This suggests that, unlike the laboratory-grown E. coli, the $365 \mathrm{~nm}$ UV light had little bactericidal effects on these surface water bacteria, "native" or "environmentally adapted" to sunlight or $365 \mathrm{~nm}$ UV light. The solar UV that reaches the surface of the earth comprises wavelengths from 290 to $380 \mathrm{~nm}$, which can be divided into two regions, UVA (380-320 nm, $8 \%$ of sunlight) and UVB (320-290 nm, $0.4 \%$ of sunlight) [50]. Although only a few tenths of a percent, UVB is recognized to be the most solar cell-damaging region. UVA is also shown to be responsible for a portion of bacterial cell killing, which is supported by the reduction in E. coli counts after their exposure to $365 \mathrm{~nm}$ UV radiation in this work. However, studies show that UVA is also able to trigger bacteria's adaptive regulatory response to sunlight, which induces 
several stress responses that help to protect against or repair cell damage [51,52]. It is not surprising that surface water bacteria, previously living under the sun, possessed effective mechanisms or were skillful at handling the damaging effects of and thus hardly affected by the $365 \mathrm{~nm}$ UV radiation. On the other hand, the presence of $5 \mathrm{mg}$ of $\mathrm{MS}-\mathrm{TiO}_{2}-10$ during the 30 min shaking under $365 \mathrm{~nm}$ UV radiation successfully produced a bacterial reduction in the LIS surface water by $62 \pm 3 \%$ (based on triplicate measurements). This demonstrated MS- $\mathrm{TiO}_{2}-10$ 's exceptional bactericidal actions that were capable of overwhelming the protective and repair strategies of these "well-customized" environmental bacteria, leading to irreversible cell death. Our nanocomposite is therefore especially promising for being applied to disinfect ballast water, which is typically surface-level water.

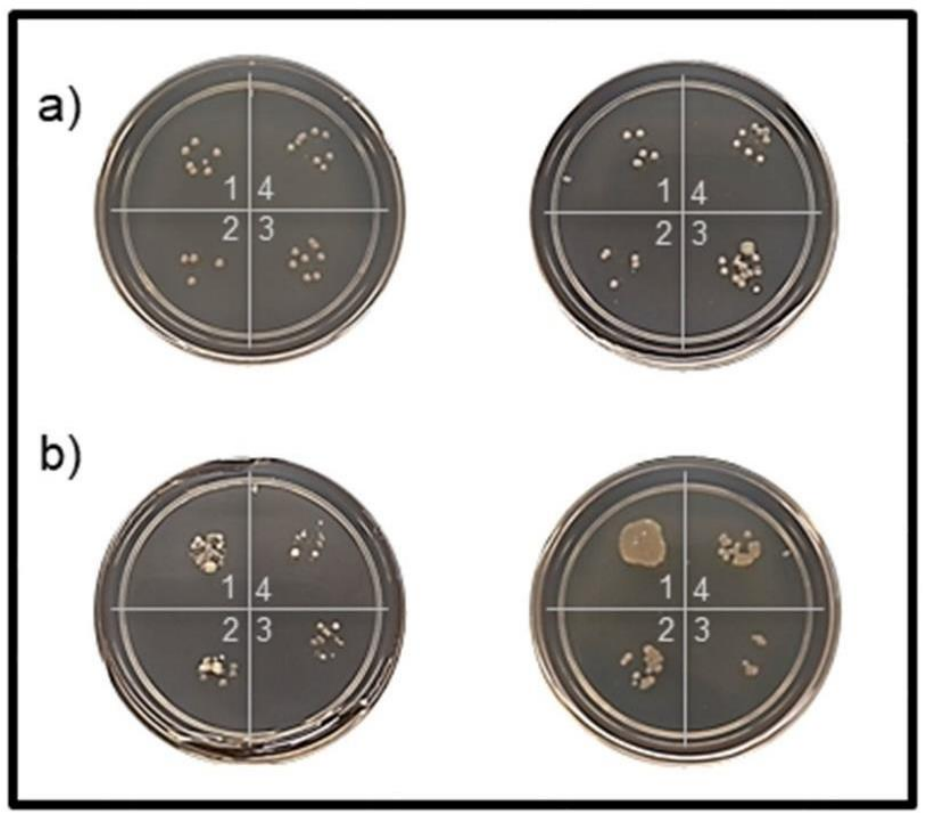

Figure 8. Disinfection of Long Island Sound (LIS) surface water under $365 \mathrm{~nm}$ UV light (a) without the presence of the nanocomposite and $(\mathbf{b})$ with the presence of $5 \mathrm{mg} / \mathrm{mL}$ of annealed $\mathrm{MS}-\mathrm{TiO}_{2}-10$ (8.7 wt.\% Ti) nanocomposite. 1 = untreated, 2, 3, 4 = after 20, 25, and 30 min treatments.

\section{Conclusions}

In summary, we have successfully synthesized a bifunctional magnetic $\mathrm{MS}-\mathrm{TiO}_{2}$ antimicrobial nanocomposite via a three-step procedure under ambient conditions and using only common equipment and chemicals. The amount of $\mathrm{TiO}_{2}$ incorporated into the nanocomposite was found to be influenced by the reaction $\mathrm{pH}$, increasing as $\mathrm{pH}$ increased from 3 to 7 and 10. Under the alkaline condition of $\mathrm{pH} 10$, the titanium content was found to generally increase with increasing TIPP precursor to MS nanocomposite ratio, from $10 \pm 4$ to $15 \pm 4 \mathrm{wt}$. $\% \mathrm{Ti}$ in this work, as estimated by the EDS measurements. Annealing at $300{ }^{\circ} \mathrm{C}$ turned $\mathrm{TiO}_{2}$ from a mostly amorphous phase with a small amount of anatase into a highly crystalline one with a high degree of anatase, an effective phase that provided antimicrobial efficacy, as confirmed by HRTEM and XRD. Under a $365 \mathrm{~nm}$ UV

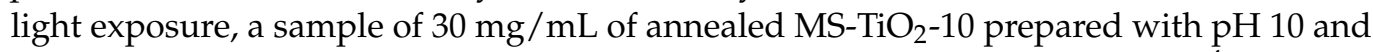
containing $12.6 \mathrm{wt}$. $\%$ Ti was shown to be able to eradicate more than $98 \%$ of a $10^{4} \mathrm{CFU} / \mathrm{mL}$ suspension of the laboratory-grown E. coli within $25 \mathrm{~min}, 25 \mathrm{~min}$ faster than the control when the $365 \mathrm{~nm}$ UV light was employed alone. The bacteria reduction rate was found to largely reflect the balance between the effects of (1) shielding by the black nanocomposite particles and (2) anatase content. Although both effects would increase with increasing nanocomposite amounts, the former reduced the bacterial reduction rate while the latter enhanced it. Increased nanocomposite amount may also worsen particle aggregation, reducing the surface area of anatase exposed to UV light, water, and dissolved oxygen, further undermining their effectiveness as biocides. Additionally, the nanocomposite 
demonstrated excellent reusability potential by producing a consistent antimicrobial effect against the model organism E. coli in $10^{4} \mathrm{CFU} / \mathrm{mL}$ suspensions via repeated cycles up to three times. Most importantly, the annealed $\mathrm{MS}^{-\mathrm{TiO}_{2}}-10$ nanocomposite in $5 \mathrm{mg} / \mathrm{mL}$ concentration was able to disinfect a real surface water sample, collected at noon on a sunny summer day and containing $500-5000 \mathrm{CFU} / \mathrm{mL}$ of different microbes. Under a $365 \mathrm{~nm}$ UV light exposure, the nanocomposite produced a bacterial reduction in this surface water sample by $62 \pm 3 \%$ within $30 \mathrm{~min}$, while the $365 \mathrm{~nm}$ UV light alone under the same condition failed to generate a noticeable biocidal effect. The highly magnetic and oxidation-resistant silica-coated magnetite cores (with a high saturation magnetization value of $33 \mathrm{emu} / \mathrm{g}$ ) enabled the nanocomposite's easy recovery for repeated use, greatly reducing material cost and the need to dispose of the used materials. Our future efforts will be directed at investigating how the efficiencies of the $\mathrm{MS}^{-\mathrm{TiO}_{2}}$ nanocomposites compare with bare $\mathrm{TiO}_{2}$, metal ion-doped $\mathrm{TiO}_{2}$, and metal ion-doped $\mathrm{MS}_{2}-\mathrm{TiO}_{2}$ to better understand and influence the electron-hole pair generation from $\mathrm{TiO}_{2}$ and the recombination of these electrons and holes. We believe the magnetic $\mathrm{TiO}_{2}$-based nanocomposites reported here will be promising in providing a feasible, safe, and eco-friendly route for inactivating bacteria in water with a wide range of applications, including disinfecting ballast water.

Author Contributions: Conceptualization, P.Y.F.; methodology, P.Y.F.; formal analysis, M.K. and P.Y.F.; investigation, M.K. (synthesis, characterization, and antimicrobial experiments), K.K. (HRTEM, EDS), C.A. (synthesis), and P.Y.F. (characterization and antimicrobial experiments); data curation, M.K. and P.Y.F.; writing-original draft preparation, M.K. and P.Y.F.; writing—review and editing, M.K., K.K., C.A. and P.Y.F.; supervision, P.Y.F.; funding acquisition, P.Y.F. All authors have read and agreed to the published version of the manuscript.

Funding: This research used resources from the Center for Functional Nanomaterials (CFN), which is a US Department of Energy Office of Science User Facility, at Brookhaven National Laboratory under Contract No. DE-SC0012704.

Institutional Review Board Statement: Not applicable.

Informed Consent Statement: Not applicable.

Data Availability Statement: Not applicable.

Acknowledgments: The authors would like to thank the USMMA Dean's Office for its generous financial support through faculty development funds. The authors would also like to thank D. Nykypanchuk of Brookhaven National Laboratory for performing the XRD measurements and assisting in the measurement result interpretation.

Conflicts of Interest: The authors declare no conflict of interest. The funders had no role in the design of the study; in the collection, analyses, or interpretation of data; in the writing of the manuscript, or in the decision to publish the results. The views expressed in this article are the authors' own and not those of the US Merchant Marine Academy, the Maritime Administration, the Department of Transportation, or the United States Government.

\section{References}

1. International Maritime Organization (IMO). Ballast Water Management. Available online: https://www.imo.org/en/OurWork/ Environment/Pages / BallastWaterManagement.aspx (accessed on 29 August 2021).

2. Seiden, J.; Way, C.; Rivkin, R. Microbial hitchhikers: Dynamics of bacterial populations in ballast water during a trans-Pacific voyage of a bulk carrier. Aquat. Invasions 2010, 5, 13-22. [CrossRef]

3. First, M.; Drake, L. Approaches for determining the effects of UV radiation on microorganisms in ballast water. Manag. Biol. Invasions 2013, 4, 87-99. [CrossRef]

4. Moreno-Andrés, J.; Romero-Martínez, L.; Acevedo-Merino, A.; Nebot, E. UV-based technologies for marine water disinfection and the application to ballast water: Does salinity interfere with disinfection processes? Sci. Total Environ. 2017, 581-582, 144-152. [CrossRef]

5. Saeed, S.; Prakash, S.; Deb, N.; Campbell, R.; Kolluru, V.; Febbo, E.; Dupont, J. Development of a site-specific kinetic model for chlorine decay and the formation of chlorination by-products in seawater. J. Mar. Sci. Eng. 2015, 3, 772-792. [CrossRef]

6. Jing, L.; Chen, B.; Zhang, B.; Peng, H. A hybrid fuzzy stochastic analytical hierarchy process (FSAHP) approach for evaluating ballast water treatment technologies. Environ. Syst. Res. 2013, 2, 10. [CrossRef] 
7. Huang, W.; Chen, X.; Fan, Y.; Li, Y. Management of contaminated drinking water source in rural communities under climate change. J. Environ. Inform. 2020. Available online: http://www.jeionline.org/index.php?journal=mys\&page=article\&op=view\& path $\% 5 B \% 5 D=202000431$ (accessed on 29 August 2021). [CrossRef]

8. Krasner, S.W.; Weinberg, H.S.; Richardson, S.D.; Pastor, S.J.; Chinn, R.; Sclimenti, M.J.; Onstad, G.D.; Thruston, A.D. Occurrence of a new generation of disinfection byproducts. Environ. Sci. Technol. 2006, 40, 7175-7185. [CrossRef]

9. Centers for Disease Control and Prevention. The safe water system—disinfection byproducts. Available online: www.cdc.gov/ safewater/chlorination-byproducts.html (accessed on 29 August 2021).

10. Shannon, M.A.; Bohn, P.W.; Elimelech, M.; Georgiadis, J.G.; Mariñas, B.J.; Mayes, A.M. Science and technology for water purification in the coming decades. Nature 2008, 452, 301-310. [CrossRef]

11. Furlan, P.Y.; Fisher, A.J.; Furlan, A.Y.; Melcer, M.E.; Shinn, D.W.; Warren, J.B. Magnetically recoverable and reusable antimicrobial nanocomposite based on activated carbon, magnetite nanoparticles, and silver nanoparticles for water disinfection. Inventions 2017, 2, 10. [CrossRef]

12. Furlan, P.Y.; Fisher, A.J.; Melcer, M.E.; Furlan, A.Y.; Warren, J.B. Preparing and testing a magnetic antimicrobial silver nanocomposite for water disinfection to gain experience at the nanochemistry-microbiology interface. J. Chem. Educ. 2017, 94, 488-493. [CrossRef]

13. Furlan, P.Y.; Furlan, A.Y.; Melcer, M.E.; Shinn, D.W.; Warren, J.B. Facile Preparation of oxidation resistant magnetite-based nanocomposites for water treatment. In Proceedings of the 17th International Conference on Emerging Trends in Materials Science and Nanotechnology, Rome, Italy, 26-27 April 2018. Available online: https://www.imedpub.com/proceedings/facilepreparation-of-oxidation-resistant-magnetitebased-nanocomposites-for-water-treatments-2156.html (accessed on 29 August 2021).

14. Furlan, P.Y.; Melcer, M.E. Removal of aromatic pollutant surrogate from water by recyclable magnetite-activated carbon nanocomposite: An experiment for general chemistry. J. Chem. Educ. 2014, 91, 1966-1970. [CrossRef]

15. Furlan, P.Y.; Ackerman, B.M.; Melcer, M.E.; Perez, S.E. Reusable magnetic nanocomposite sponges for removing oil from water discharges. J. Ship Prod. Des. 2017, 33, 227-236. [CrossRef]

16. Fisher, A.J.; Keeley, M.M.; Lane, J.M.; Furlan, P.Y. Spectroscopic evaluation of removal efficiency for a pharmaceutical pollutant in water using a magnetite-activated carbon nanocomposite. J. Chem. Educ. 2019, 96, 751-755. [CrossRef]

17. Singh, H.; Bhardwaj, N.; Arya, S.K.; Khatri, M. Environmental impacts of oil spills and their remediation by magnetic nanomaterials. Environ. Nanotechnol. Monit. Manag. 2020, 100305. [CrossRef]

18. Liu, B.; Chen, B.; Zhang, B.; Song, X.; Zeng, G.; Lee, K. Photocatalytic ozonation of offshore produced water by TiO2 nanotube arrays coupled with UV-LED irradiation. J. Hazard. Mater. 2020, 402, 123456. [CrossRef] [PubMed]

19. Cao, Y.; Zhang, B.; Zhu, Z.; Rostami, M.; Dong, G.; Ling, J.; Lee, K.; Greer, C.W.; Chen, B. Access-dispersion-recovery strategy for enhanced mitigation of heavy crude oil pollution using magnetic nanoparticles decorated bacteria. Bioresour. Technol. 2021, 337, 125404. [CrossRef]

20. Nagamine, M.; Osial, M.; Jackowska, K.; Krysinski, P.; Widera-Kalinowska, J. Tetracycline photocatalytic degradation under CdS treatment. J. Mar. Sci. Eng. 2020, 8, 483. [CrossRef]

21. Ramutshatsha-Makhwedzha, D.; Ngila, J.C.; Ndungu, P.; Nomngongo, P.N. Ultrasound assisted adsorptive removal of Cr, Cu, Al, $\mathrm{Ba}, \mathrm{Zn}, \mathrm{Ni}, \mathrm{Mn}, \mathrm{Co}$ and Ti from seawater using $\mathrm{Fe}_{2} \mathrm{O}_{3}-\mathrm{SiO}_{2}-\mathrm{PAN}$ nanocomposite: Equilibrium kinetics. J. Mar. Sci. Eng. 2019, 7, 133. [CrossRef]

22. Lee, S.; You, K.H.; Park, C.B. Highly photoactive, low bandgap $\mathrm{TiO}_{2}$ nanoparticles wrapped by graphene. Adv. Mater. 2012, 24, 1084-1088. [CrossRef]

23. Goei, R.; Lim, T.-T. Ag-decorated $\mathrm{TiO}_{2}$ photocatalytic membrane with hierarchical architecture: Photocatalytic and anti-bacterial activities. Water Res. 2014, 59, 207-218. [CrossRef]

24. Fonseca-Cervantes, O.R.; Pérez-Larios, A.; Arellano, V.H.R.; Sulbaran-Rangel, B.; González, C.A.G. Effects in band gap for photocatalysis in $\mathrm{TiO}_{2}$ support by adding gold and ruthenium. Processes 2020, 8, 1032. [CrossRef]

25. Banerjee, S.; Gopal, J.; Muraleedharan, P.; Tyagi, A.K.; Raj, B. Physics and chemistry of photocatalytic titanium dioxide: Visualization of bactericidal activity using atomic force microscopy. Curr. Sci. 2006, 90, 1378-1383.

26. de Dicastillo, C.L.; Correa, M.G.; Martínez, F.B.; Streitt, C.; Galotto, M.J. Antimicrobial effect of titanium dioxide nanoparticles. IntechOpen 2021. Available online: https:/ / www.intechopen.com/books/antimicrobial-resistance-a-one-health-perspective/ antimicrobial-effect-of-titanium-dioxide-nanoparticles (accessed on 29 August 2021). [CrossRef]

27. Furlan, P.Y.; Furlan, A.Y.; Kisslinger, K.; Melcer, M.E.; Shinn, D.W.; Warren, J.B. Water as the solvent in the stober process for forming ultrafine silica shells on magnetite nanoparticles. ACS Sustain. Chem. Eng. 2019, 7, 15578-15584. [CrossRef]

28. Alvarez, P.; Jaramillo, J.; López-Piñero, F.; Plucinski, P.K. Preparation and characterization of magnetic $\mathrm{TiO}_{2}$ nanoparticles and their utilization for the degradation of emerging pollutants in water. Appl. Catal. B Environ. 2010, 100, 338-345. [CrossRef]

29. Pang, S.C.; Kho, S.Y.; Chin, S.F. Fabrication of Magnetite/Silica/Titania Core-Shell Nanoparticles. J. Nanomater. 2012, 2012, 1-6. [CrossRef]

30. Wang, R.; Wang, X.; Xi, X.; Hu, R.; Jiang, G. Preparation and photocatalytic activity of magnetic $\mathrm{Fe}_{3} \mathrm{O}_{4} / \mathrm{SiO}_{2} / \mathrm{TiO}_{2} \mathrm{Composites}$. Adv. Mater. Sci. Eng. 2012, 2012, 1-8. [CrossRef]

31. Rashid, J.; Barakat, M.A.; Ruzmanova, Y.; Chianese, A. $\mathrm{Fe}_{3} \mathrm{O}_{4} / \mathrm{SiO}_{2} / \mathrm{TiO}_{2}$ nanoparticles for photocatalytic degradation of 2-chlorophenol in simulated wastewater. Environ. Sci. Pollut. Res. 2014, 22, 3149-3157. [CrossRef] 
32. Kunarti, E.; Syoufian, A.; Budi, I.; Pradipta, A. Preparation and properties of $\mathrm{Fe}_{3} \mathrm{O}_{4} / \mathrm{SiO}_{2} / \mathrm{TiO}_{2}$ core-shell nanocomposite as recoverable photocatalyst. Asian J. Chem. 2016, 28, 1343-1346. [CrossRef]

33. Mortazavi-Derazkola, S.; Salavati-Niasari, M.; Amiri, O.; Abbasi, A. Fabrication and characterization of $\mathrm{Fe}_{3} \mathrm{O}_{4} @ \mathrm{SiO}_{2} @ \mathrm{TiO}{ }_{2} @ \mathrm{Ho}_{0}$ nanostructures as a novel and highly efficient photocatalyst for degradation of organic pollution. J. Energy Chem. 2017, 26, 17-23. [CrossRef]

34. Shahid, M.; McDonagh, A.; Kim, J.H.; Shon, H.K. Magnetised titanium dioxide $\left(\mathrm{TiO}_{2}\right)$ for water purification: Preparation, characterisation and application. Desalination Water Treat. 2014, 54, 979-1002. [CrossRef]

35. Magaña-López, R.; Zaragoza-Sánchez, P.; Jiménez-Cisneros, B.; Chávez-Mejía, A. The use of $\mathrm{TiO}_{2}$ as a disinfectant in water sanitation applications. Water 2021, 13, 1641. [CrossRef]

36. Simonsen, M.E.; Søgaard, E.G. Sol-gel reactions of titanium alkoxides and water: Influence of pH and alkoxy group on cluster formation and properties of the resulting products. J. Sol-Gel Sci. Technol. 2010, 53, 485-497. [CrossRef]

37. Kalska-Szostko, B.; Wykowska, U.; Satuła, D.; Nordblad, P. Thermal treatment of magnetite nanoparticles. Beilstein J. Nanotechnol. 2015, 6, 1385-1396. [CrossRef] [PubMed]

38. Topal, U.; Aksan, M.A. Phase stabilization of magnetite $\left(\mathrm{Fe}_{3} \mathrm{O}_{4}\right)$ nanoparticles with $\mathrm{B}_{2} \mathrm{O}_{3}$ addition: A significant enhancement on the phase transition temperature. J. Magn. Magn. Mater. 2016, 406, 123-128. [CrossRef]

39. Ruff. Anatase X-ray Diffraction Pattern Computed Using Published Structural Information. Available online: https://rruff.info/ anatase/display=default/R060277 (accessed on 29 August 2021).

40. Ruff. Rutile X-ray Diffraction Pattern Computed Using Published Structural Information. Available online: https://rruff.info/ rutile/display=default/R040049 (accessed on 29 August 2021).

41. Ruff. Magnetite X-ray Diffraction Pattern Computed Using Published Structural Information. Available online: https://rruff. info/magnetite/display=default/R061111 (accessed on 29 August 2021).

42. Ruff. Hematite X-ray Diffraction Pattern Computed Using Published Structural Information. Available online: https://rruff.info/ hematite/display=default/R110013 (accessed on 29 August 2021).

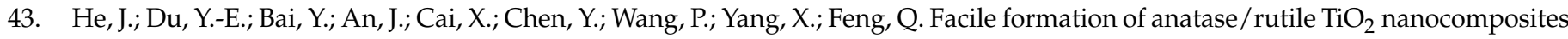
with enhanced photocatalytic activity. Molecules 2019, 24, 2996. [CrossRef]

44. Soler-Illia, G.; Louis, A.; Sanchez, C. Synthesis and characterization of mesostructured titania-based materials through evaporationinduced self-assembly. Chem. Mater. 2002, 14, 750-759. [CrossRef]

45. Zeitler, V.A.; Brown, C.A. The infrared spectra of some Ti-O-Si, Ti-O-Ti and Si-O-Si compounds. J. Phys. Chem. 1957, 61, 1174-1177. [CrossRef]

46. Cuenca, J.A.; Bugler, K.; Taylor, S.; Morgan, D.; Williams, P.; Bauer, J.; Porch, A. Study of the magnetite to maghemite transition using microwave permittivity and permeability measurements. J. Phys. Condens. Matter 2016, 28, 106002. [CrossRef] [PubMed]

47. Simon-Deckers, A.; Loo, S.; Mayne-L’hermite, M.; Herlin-Boime, N.; Menguy, N.; Reynaud, C.; Gouget, B.; Carriere, M. Size-, composition- and shape-dependent toxicological impact of metal oxide nanoparticles and carbon nanotubes toward bacteria. Environ. Sci. Technol. 2009, 43, 8423-8429. [CrossRef]

48. Rickerby, D.G. Nanostructured titanium dioxide for photocatalytic water treatment. Nanomater. Environ. Prot. 2014, $2014,169-182$. [CrossRef]

49. Save the Sound. Long Island Sound Report Card. Available online: https://www.savethesound.org/report-card (accessed on 29 August 2021).

50. Coohill, T.P.; Sagripanti, J.-L. Bacterial inactivation by solar ultraviolet radiation compared with sensitivity to $254 \mathrm{~nm}$ radiation. Photochem. Photobiol. 2009, 85, 1043-1052. [CrossRef] [PubMed]

51. Nelson, K.L.; Boehm, A.B.; Davies-Colley, R.J.; Dodd, M.C.; Kohn, T.; Linden, K.G.; Liu, Y.; Maraccini, P.A.; McNeill, K.; Mitch, W.A.; et al. Sunlight-mediated inactivation of health-relevant microorganisms in water: A review of mechanisms and modeling approaches. Environ. Sci. Process. Impacts 2018, 20, 1089-1122. [CrossRef] [PubMed]

52. Hoerter, J.D.; Arnold, A.A.; Kuczynska, D.A.; Shibuya, A.; Ward, C.; Sauer, M.G.; Gizachew, A.; Hotchkiss, T.M.; Fleming, T.J.; Johnson, S. Effects of sublethal UVA irradiation on activity levels of oxidative defense enzymes and protein oxidation in Escherichia coli. J. Photochem. Photobiol. B 2005, 81, 171-180. [CrossRef] 